replika

DOI: $10.32564 / 112.7$

2019 (112): 63-76.

(C) A szerzö(k) 2019

replika.hu/replika/112

\title{
Pál Eszter
}

\section{Sımmel Amerıkában: az Idegen és a marginálıs ember}

\begin{abstract}
Absztrakt: A tanulmány Georg Simmel idegenkoncepciójának befogadását tárgyalja a korai amerikai szociológiában. Az írás röviden áttekinti a korai amerikai szociológia közegét, az európai elméletek megjelenését és ezek átvételének csatornáit. Bemutatja, hogy Simmel amerikai recepciójában a személyes kapcsolatoknak és az általa használt fogalmak adaptálhatóságának egyaránt jelentősége volt. Különösen igaz ez a Simmel 1908-ban megjelentetett Soziologie című müvében használt idegen fogalmára, jóllehet amerikai hatása korábbra nyúlik vissza. A tanulmány kiemelt figyelmet szentel a chicagói szociológiának, hiszen a személyes és tematikai kapcsolódásnak köszönhetően Chicago lett az amerikai Simmel-recepció központja. Az írás kitér a chicagói szociológia vezető személyiségeinek, Albion Smallnak és Robert E. Parknak ebben játszott szerepére, majd bemutatja, hogy az idegen fogalmát Park miként értelmezte át a marginális ember koncepciójában, és hogyan alkalmazta ugyanezt a fogalmat Schütz fenomenológiai megközelítésben.
\end{abstract}

Kulcsszavak: Georg Simmel, korai amerikai szociológia, chicagói szociológia, az idegen szociológiája, a marginális ember, Robert E. Park 


\section{Az amerikai szociológia kezdetei és az európai társadalomtudósok}

A korai (19. század végi, 20. század eleji) amerikai szociológia sajátos kettősséget mutat: az intézményes keretek kialakításában élen járt, ám saját elméleti teljesítményt sokáig nem tudott felmutatni. Így - bár nagyon határozott hazai színárnyalatokkal gazdagítva, de - mégiscsak európai szerzők koncepcióit vette át. Minthogy az amerikai társadalmi viszonyok jelentősen eltértek az európai kontextustól, az importált fogalmak, elméletek az átvétel során ugyancsak lényegesen átalakultak. Az amerikai társadalomtudósok mindenekelött használható koncepciókat kerestek, ami azzal járt, hogy az eredetileg európai elméletek a sajátosan amerikai közegben végül maguk is sajátosan amerikaivá váltak. Az alábbi tanulmányban ennek az átvételnek egy apró, ám annál jelentősebb darabjával foglalkozom: Georg Simmel eredetileg 1908-ban megjelent néhány oldalas szövegének, az „Exkurzus az idegenről” (2004) címú írásnak az amerikai recepcióját vizsgálom. Írásomban a befogadási folyamat első állomásait mutatom be, hiszen e korai időszakot vizsgálva válik nyilvánvalóvá Simmel koncepciójának jelentősége az amerikai szociológia további alakulásában. Ám ehhez mindenekelőtt szükséges röviden kitérnem arra a tágabb kontextusra is, amelyben a német társadalomtudós néhány fontos írása befogadásra talált.

$\mathrm{Az}$ amerikai polgárháború vége, vagyis az 1865-ös év a dinamikus fejlődés évtizedeinek kezdetét is jelezte. A fejlettebb európai országokhoz hasonlóan itt is gyors ütemű indusztrializációs folyamatok zajlottak le. A nagyarányú belső migrációval párhuzamosan azonban a tempósan fejlődő amerikai társadalmi és gazdasági életet - persze elsősorban a városi központokét - az Európából több hullámban érkező bevándorlók milliói is alakították. Az európai bevándorlási hullámoknak, az urbanizációnak és az amerikai gazdaság- és társadalomtörténet egyéb jellegzetességeinek (például a rabszolgaság felszámolása után is megmaradó faji szegregációnak és társadalmi egyenlőtlenségnek) köszönhetően létrejövő sajátosan amerikai multikulturális metropoliszok - az ekkor még "olvasztótégelyeknek” gondolt nagyvárosok - az amerikai szociológia korai vizsgálódásainak nem csak keretét, de legfontosabb kutatási tárgyát is adták.

A kapitalista gazdasági és társadalmi átalakulások közepette - s a szociológia tekintetében döntő módon - a felsőoktatási szerkezetet is gyökeres reformoknak vetették alá, mely reformok minőségi és mennyiségi szempontból egyaránt megújulást hoztak. A szociológia számára pedig éppen e megújult és kiterjedt keretek és források tették lehetővé az európaihoz képest gyors és látványos sikereket hozó intézményesülést, ${ }^{1} \mathrm{~s}$ nem véletlenül éppen itt, egész pontosan Chicagóban hozták létre az első szociológiai (és antropológiai) tanszéket 1892-ben. Ám miközben az intézményesedés sikereit tekintve Európában legfeljebb a francia szociológia vehette fel a versenyt az amerikaival, addig elméleti tartalmait ez utóbbi az első néhány évtizedben jórészt Európából importálta.

Az európai recepciónak több csatornája is volt. Az első néhány évtizedben legfőbb vonatkoztatási keretként használt evolúciós és organicista elméletek tengerentúli diffúziója elsősorban a brit szerzőktől maguktól indult ki: többen szerződést kötöttek amerikai kiadókkal, így müveik az amerikai közönséghez közvetlenül juthattak el. ${ }^{2}$ A századforduló után azonban e megközelítés itt is - csakúgy, mint Európában - veszített népszerűségéből, bár egy-egy

1 A korai amerikai szociológiával máshol részletesebben foglalkoztam (Pál 2009). A témához lásd még Némedi (2005).

2 Ehhez lásd Pál (2015). 
eleme a hamarosan saját hangjukra találó amerikai szociológusok repertoárjából sem tünt el teljesen. (Ilyen volt például az organicista hasonlat, amelyet Park a városszociológia alapjait lefektető írásaiban előszeretettel alkalmazott, de amely még Talcott Parsons 1950-es években kidolgozott rendszerelméletének is a kiindulási pontját képezte. ${ }^{3}$ )

A brit evolucionisták mellett leginkább a német társadalomtudósok hatása nevezhető számottevőnek e korai időszak amerikai gondolkodásában. Ám a németek más csatornán érkeztek ide: maguk az amerikai szociológusok utaztak Németországba, ${ }^{4} \mathrm{~s}$ tanulmányozták a helyszínen e teóriákat, melyeket azután hazatérve lefordítottak, oktattak és felhasználtak saját írásaikban.

Összességében azonban kevés európai szerző gyakorolt igazán mély és maradandó hatást az egyre bővülő és professzionalizálódó amerikai szociológiai gondolkodásra. Luther Bernard 1927-es felmérésekor, amelyben a szerző szociológusokat kérdezett különféle szakmai témákról, már kisebbségben voltak azok, akik egyáltalán említettek európai elméletet a számukra fontos hatások között (vö. Levine et al. 1976). A 20. század eleji amerikai szociológiai diskurzusba kevés európai teoretikus tudott szervesen beépülni, s még kevesebben voltak azok, akik hatása tartósnak bizonyult - Spencer után Marx, Weber, Durkheim, s végül, de egyáltalán nem utolsósorban Simmel volt az, aki a legkorábbi időktől ${ }^{5}$ kezdve mélyebben alakította az amerikai szociológia középponti figuráinak gondolkodását.

Az amerikai szociológia e korai szakaszának meghatározó figurája, a chicagói szociológiai tanszék első vezetője és az American Journal of Sociology első, alapító főszerkesztője, Albion Small volt az, akinek a leginkább köszönhető, hogy Simmel később jelentős szerepet tudott játszani Amerikában. Small 1880-ban utazott Berlinbe tanulni, s itt ismerkedett meg az ekkor még egyetemista Simmellel. Későbbi európai utazásai során többször felkereste, és tartós szakmai kapcsolatot alakított ki vele. Ennek keretében a századforduló körüli időszakban Small több tanulmányt is megjelentetett az American Journal of Sociologyban Simmeltöl, így írásainak már korán megkezdődhetett szélesebb körü recepciója is. A szakmai kapcsolat ápolásának egyik csatornája a rendszeres levelezés volt, ám még lényegesebb, hogy Small számos tanítványát is Berlinbe küldte egyetemi tanulmányaik elmélyítése céljából. Így jutott ki Simmelhez (és másokhoz) tanulni többek között Charles Ellwood, Nicholas Spykman, s a jelen tanulmány szempontjából legfontosabb: Robert E. Park maga is (Levine et al. 1976).

Ha Smallt tekinthetjük a kiindulási pontnak a simmeli megközelítés amerikai recepciójában, akkor Park volt ugyanennek a folyamatnak a legfőbb katalizátora, de egyúttal ő volt az is, aki - mint látni fogjuk - Simmel fogalmi készletének „amerikanizálását”, vagyis sajátos átértelmezését elkezdte, s ezzel az „,amerikai Simmel” megalkotásának kulcsfigurája lett. Park így több tekintetben is követte Smallt: később chicagói tanszékvezetőként meghatározó szerepet játszott Simmel importjában ő maga is. Simmel iránti érdeklődése igen aktív volt: jó néhány szövegét maga fordította le angolra, sőt azokat kötelező olvasmányként az egyetemi curriculumba illesztette. 1921-es, Burgess-szel közösen összeállított, a szociológiai kánont kijelölő, tankönyvként használt kötetük (Park és Burgess 1921) tíz Simmel-tanulmányt közölt - ahogy Levine és szerzőtársai (1976) rámutatnak: minden más szerzőnél többet -, ezzel

3 Vö. Park (2000 [1926]), Parsons (2000 [1951]) és Pál (2004).

4 Más európai országba is utaztak persze az amerikai társadalomtudósok, de elsődleges célpontjuk mindenképpen Németország volt.

5 Weber és Durkheim esetében érdemes pontosítani: az amerikai szociológia legkorábbi évtizedeiben még ismeretlenek voltak, és csak az 1920-as években - Talcott Parsonsnak köszönhetően - indult meg recepciójuk. 
pedig óriási lökést adott Simmel amerikai befogadásának. Olyannyira, hogy 1925-ben N. J. Spykman már The Social Theory of Georg Simmel címmel egy átfogó ismertetéssel bevezetett kötetet állított össze Simmel müveiből. A recepciót mélyítette a világháború elöl Amerikába menekülő európai társadalomtudósok munkássága is, akik közül többen is fordították a simmeli életmű korábban angolul nem elérhető szövegeit - ezek közül Kurt Wolff 1950-es kötete, a The Sociology of Georg Simmel különösen nagy jelentőségűnek bizonyult (Levine et al. 1976).

A következőkben két olyan szerzőről lesz szó, akik a simmeli életmű egy fontos darabjának, az idegen koncepciójának nem egyszerü átvételével, hanem újraértelmezésével járultak hozzá a Simmel-recepcióhoz, illetve a simmeli koncepció amerikai verziójának sikeréhez. Egyikükről, Robert Parkról már volt szó: ő egy 1928-ban megjelent tanulmányban adaptálta, amerikanizálta Simmel idegenkoncepcióját, és az „amerikai idegen”, vagyis Park „marginális ember”-e az amerikai szociológiai diskurzus sürüjébe került. A másik itt vizsgált teoretikus Alfred Schütz, az Európából bevándorló társadalomtudós, aki 1944-ben írta meg azóta klasszikussá érett tanulmányát „Az idegen” címmel (Schütz 1984 [1944]), amelyben az eredeti fogalom szociálpszichológiai értelmezését alapozta meg. Mindezek előtt azonban Simmel eredeti szövegét mutatom be röviden, különös tekintettel azokra az elemeire, amelyek a későbbi amerikai olvasatban hangsúlyosabbá válnak vagy éppen háttérbe szorulnak.

\section{Miért éppen Simmel?}

Joggal merülhet fel a kérdés, hogy az európai szerzők közül miért Simmel elmélete tudta a legmélyebb, legtartósabb hatást gyakorolni a korai amerikai szociológiai gondolkodásra, vagy legalábbis miért került a legfeljebb két-három olyan szerző közé, akikkel kapcsolatban ez a kérdés egyáltalán felvethető.

A kérdés persze nem válaszolható meg kimerítően, hiszen a tudományos elméletek recepciójában mindig számos tényező játszhat közre, némelyik pedig mindenképpen esetleges. Simmel esetében egyértelmüen óriási szerepe volt a személyes kapcsolatoknak: semmi esetre sem elhanyagolható szerencsés tényező, hogy éppen Albion Small, az amerikai szociológia kezdeti időszakának legfontosabb szereplője, motorja és szervezője volt az, aki Berlinbe utazott, s ott Simmellel személyes jó kapcsolatot alakított ki, amelyet a későbbiekben sem volt rest intenzíven ápolni. Azt hiszem, bátran kijelenthetjük, hogy Small németországi tanulmányútja és későbbi szerepvállalása nélkül Simmel amerikai recepciója másként alakul - talán később kezdődik, de lehet, hogy akkor sem válik olyan átfogóvá.

Ám Small (és persze ugyanígy Park) közremüködése önmagában korántsem lehetett elegendő. Simmel életmüvéből a szociológia diszciplináris lehatárolásának kísérlete mellett leginkább a nagyvárosi élet és az idegenség szociológiai értelmezése gyakoroltak a II. világháború előtti amerikai szociológiára igazán fontos hatást, ez pedig azt - az egyébként korántsem meglepő - feltevést támasztja alá, hogy Simmel amerikai népszerüségében a nagyon is konkrét tematikai kapcsolódás legalább akkora szerepet játszott, mint a személyes kapcsolatok kölcsönös ápolása.

Small, de még Park első berlini látogatásakor (1899-ben) sem született meg „A nagyváros és a szellemi élet” (ennek eredeti megjelenési éve 1903) vagy „Exkurzus az idegenről” című szöveg (Simmel 1973 [1903], 2004 [1908]). Jaworskinak (1995) feltehetően igaza van abban, hogy amit Small korán meglátott Simmelben, az egy olyan szociológia lehetősége volt, mely 
nagyon is releváns volt az 1880-as évek és a polgárháború utáni időszak szabadversenyes kapitalizmusával átitatott Amerikája számára, mert egy olyan, alapvetően morális, társadalomjobbító szándékokat instrumentalizáló (ám semmiképpen sem baloldali) autonóm megközelítés alapjául szolgálhatott, amely a modern, urbanizálódó társadalom problémáira kínált megoldást. Park pedig leginkább a századforduló után is domináns rasszista diskurzussal szemben keresett konceptuális keretet a multikulturalizmus, az etnikai érintkezés kérdéseire.

Nyilvánvaló, hogy az amerikai szociológusok az őket körülvevő társadalmi jelenségekről gondolkodva, adott társadalmi problémák felöl olvasták Simmelt. És igaz ugyan, hogy - amint Jaworski (1995) hangsúlyozza - nem az American Journal of Sociology volt az egyetlen, de még csak nem is az első olyan amerikai folyóirat, amelyik Simmel-tanulmányokat közölt, mégis Small volt az, aki szisztematikus „kampányba” kezdett többek között az AJS lapjain annak érdekében, hogy német kollégájának írásait minél szélesebb körben megismertesse, ezt pedig Park nem kevesebb intenzitással folytatta. Mindennek köszönhetően egyértelmüen Chicago lett a Simmel-recepció kiindulási pontja Amerikában.

Chicago természetesen másfajta jelentőséggel is bírt a történetben. A nagyvárosi lét Simmel által leírt tapasztalata, a modern metropoliszokban összezsúfolódó milliók közötti kapcsolat idegensége nemcsak Berlinben volt átélhető. Ahogy másutt (Pál 2019) megfogalmaztam: ${ }^{6}$ a Simmel által voltaképpen térbeli viszonyként definiált „idegenség”, vagyis a társadalmi, érzelmi távolság kérdése nem véletlenül éppen akkor válik relevánssá Berlinben és Chicagóban egyaránt, amikor a modern városi központokban együtt élő emberek közötti sokdimenziós relációban a térbeli közelség érzelmi és társadalmi távolsággal összekapcsolódva jelenik meg. Park a városszociológia kiinduló gondolatát fogalmazza meg, amikor megállapítja, hogy a létrejött metropoliszokban megfigyelhető földrajzi elkülönülés, szegregáció azt jelzi, hogy a földrajzi távolság egyúttal társadalmi is, a társadalmi viszonyok pedig szó szerint „letérképezhető”” (Park 2000 [1926]). Másfelől tovább árnyalható a koncepció, hiszen ugyanennek az időszaknak a társadalmi, gazdasági, demográfiai változásai miatt a „társadalmi távolság” fogalmának szerepe megnő, önálló jelentést kap, mivel a modern társadalmi viszonyok részben felülírják a közelség s távolság fizikai dimenzióját. Az „idegen” Simmelnél és Schütznél, vagy a „marginális ember” Parknál és másoknál - mint látni fogjuk - társadalmi, kulturális és emocionális tekintetben egyszerre van közel és távol a többiektől, miközben a viszony éppen azáltal jön egyáltalán létre, hogy földrajzi értelemben lecsökken a köztük lévő távolság. ${ }^{7}$

6 Idézett tanulmányomban az „idegenség” és a „marginalitás” koncepcióit mint metaforákat vizsgálom, s az elemzés ott a térbeliség metaforikus kifejezésére és ennek szociológiai szerepére összpontosít. Erre az egyébként fontos szempontra ezért a jelen tanulmányban részletesebben nem térek ki.

7 Mindezzel szorosan összefügg, hogy az 1920-as évektől kezd elterjedni a „társadalmi távolság” fogalma. Közismert, hogy Emory Bogardus empirikusan megragadható, skálával mérhető tartalmat tulajdonított a kifejezésnek, a fogalom látványos - amerikai és nemzetközi - karrierjét indítva ezzel el. Kevésbé ismert azonban, hogy ennek kiindulópontját Simmel, méghozzá elsősorban az „idegen” koncepciójának amerikai adaptálása adta. A jelen tanulmány kereteibe nem fér bele a történet ezen ágának rekonstrukciója, de érdemes azért arra felhívni a figyelmet, hogy - amint azt alább is látni fogjuk - az eredeti elgondolás az átvétel során nagymértékben módosult. Ez már Parknál is látható, a Bogardus-féle empirikus kutatási eszközként megkonstruált skála pedig igen lényegesen eltér az azt ihlető simmeli elképzeléstől. Az eltérés legfőbb irányát alább mutatom be, de korántsem kimerítő módon. Nem lesz szó például arról az ugyancsak felvethető kérdésről, hogy a „társadalmi távolság” Bogardus értelmezésében mennyit őriz meg a kifejezés szó szerinti, geometriai, fizikai jelentéséből, illetve, hogy ennek a dimenziónak a kikopása elvesz-e valamit a koncepció értékéből, amint azt például Philip Ethington állítja (1997). Itt tehát csupán annyit szögeznék le, hogy a koncepció elterjedésében fontos szerepet játszott a fizikai és a társadalmi dimenzió divergálása, amely a századforduló körül felgyorsult változások nyomán rendkívül látványossá vált. 


\section{Az „Exkurzus az idegenröl” Amerikában}

A Park vezetése alatt álló szociológiai tanszéken művelt kutatás s az ahhoz kapcsolódó intézményi háttér és reputáció voltaképpen a polgárháború után induló professzionalizálódási folyamatot tetőzte be az amerikai szociológia történetében. Ennek egyik legfőbb elemeként - nem utolsósorban a chicagói szociológiával korábban szervesen összefonódó reformmozgalmak és az egyéb, immár „amatőrnek” minősített tevékenységektől jól látható távolság jegyében - a szociológiát Park és Burgess 1921-es, tankönyvként használt műve olyan tudományként határozta meg, amely a társadalmi problémákat pusztán a tudás megszerzéséért magáért, nem pedig a problémák orvoslása céljából tanulmányozza. E mü egyszerre jelzi, hogy miképp gondolkodtak tudományuk szerepéről a kor chicagói szociológusai, s azt is, hogy mindezt milyen elméleti tájékozódási keretek között képzelték el.

Ezt a könyvet lényegében mindenki ismerte, aki a korszakban szociológiával foglalkozott Amerikában, az itt közreadott írások ezért kiemelt figyelmet kaptak. A fentiek fényében talán nem meglepö, hogy Simmel 1908-as, idegenről szóló szövege is ezek között volt. McLemore (1970) nagy jelentőséget tulajdonít annak a kontextusnak is, amelybe az írást Parkék a könyvön belül illesztették: a későbbi interpretáció szempontjából szimbolikusnak, s egyszersmind meghatározónak tekinti, hogy Simmel Exkurzusa Werner Sombart eredetileg 1915-ben megjelent, migrációról szóló szövege után következik a kötetben. McLemore szerint a két szöveg együttes közlése adott tápot a későbbi értelmezésben tükröződő zavarnak: a Simmelnél még hangsúlyosabb dimenzió, vagyis az idegenség sajátos társadalmi pozícióként történő leírása az amerikai recepcióban keveredik az eredetileg kevésbé domináns pszichológiai, szociálpszichológiai vonulattal. Ahogy alább látni is fogjuk, e megállapítás nem alaptalan. A későbbi diskurzus, mondja McLemore, nem végezte el a két szál fogalmi elválasztását és tisztázását, sőt azokat teljesen összezavarta, emiatt pedig „az idegen szociológiája” nem tudott valóban jól müködő kutatási iránnyá válni (McLemore 1970).

A két aspektus valóban tovább él, s talán az is elmondható, hogy nem mindig jelennek meg fogalmilag tisztán. Nehéz volna persze megállapítani, hogy a konceptuális inkonzisztenciában a Sombart-szövegnek mekkora volt a szerepe, ám annak minden bizonnyal lehetett jelentősége, hogy az új szövegkörnyezetben Simmel írása kikerült a régi, 1908-as kontextusból, holott az szervesebben hozzátartozott, mint az amerikai tanulmánykötetben az előtte lévő lapokon közölt cikk.

Az „Exkurzus az idegenről” címü néhány oldalas írás (Simmel 2004 [1908]), jelen tanulmány tárgya, eredetileg Simmel egyik legfontosabb munkájában, az 1908-as Soziologiebanlátott napvilágot, méghozzá az ottani föszöveghez mintegy kitéröként illesztett, azonban nagyon is jelentős szövegként. Amint máshol (Pál 2019) részletesebben bemutatom, ${ }^{8}$ az idegen fogalma Simmelnél alapvetően a térbeliség viszonylatából indul ki, s tágul - a térbeliségre utaló további metaforák segítségével - komplex jelentéstartalommal bíró, árnyalt koncepcióvá. Bár itt nem a metaforikus fogalomhasználat müködése érdekel, e dimenziótól jelen írásban sem tekinthetek el teljesen.

8 A következő néhány bekezdés részben azonos átvételeket tartalmaz a hivatkozott tanulmányból. Abban ugyancsak összefoglalom az itt is elemzett szövegek föbb gondolatmenetét, amelynek rekonstruálására az alábbiakban is szükség van. Mivel azonban teljesen mások az elemzési szempontok, az itteni írásban jóval részletesebben tárgyalom az Amerikában megjelent szövegeket és fogadtatásukat. 
Jóllehet, az „idegen” kifejezés önmagában nem utal a térbeliségre, a szöveg Simmel tervezett térszociológiai projektjének részeként értelmezhető - s éppen ez az, ami az amerikai kiadás kontextusában elvész. Az Exkurzus felütése azonban rögtön egyértelmüsíti, hogy az idegen fogalma Simmelnél a közelség-távolság, vagyis a tér dimenziójában nyer értelmet. „Amennyiben a vándorlás egy meghatározott térbeli ponttól való elszakadásként a fogalmi ellentétét képezi egy ilyen ponthoz való rögzültségnek, akkor az »idegen « szociológiai formája bizonyos értelemben e két meghatározás egységét képezi” - kezdi Simmel (2004: 56). Mindjárt a legelső mondatban világossá teszi tehát, hogy az idegenség általa felvázolt koncepciója térbeli viszonyok sajátos kombinációjának társadalmi lecsapódása: a tényleges fizikai relációkat tekintve paradox térbeli állapot egy szociológiai értelemben nagyon is koherens, de legalábbis jellegzetes formában, az idegenségben kel életre.

A „tér kapcsán kialakított viszony - folytatja Simmel - az emberhez való viszonyoknak egyrészt a feltétele, másrészt a szimbóluma” (uo.). Fontos gondolat ez, hiszen a 20. századi szociológia nem egy irányzatának szolgált kiindulópontjául: ${ }^{9}$ a térbeli viszonyok társadalmi viszonyok is egyben, állapítja meg számos városszociológiai, kisebbségszociológiai és egyéb kutatás. Ám itt Simmel a „feltétel” és „szimbólum” kifejezések mellett éppen azt az aspektust hagyja említés nélkül, amely pedig az idegenség elemzése során végig középponti elem, mely e létállapot voltaképpen legsajátabb vonása: az „elszakadás” és „rögzültség” együttese. ${ }^{10} \mathrm{Az}$ idegen az az ember, aki egyszerre van közel és távol a csoporttól; nem vándor, „aki ma jön, s holnap megy”, hanem az, aki „ma jön s holnap is marad”, de a távozás „vágyát még nem győzte le" (uo.).

Még nyilvánvalóbb az idegen mint metafora térbeli jellege a következő mondatból: az idegen „adott térbeli környezethez vagy a térbelivel analóg határvonalú környezethez rögzül, de helyzetét lényegileg az határozza meg, hogy nem tartozik ide már eleve, és olyan minőségeket emel be ebbe a térbe, amelyek nem innen származnak és nem is származhatnak innen" (uo.). Így végül eljutunk a simmeli meghatározás lényegéhez: az idegenség azt jelenti, hogy „a távoli közel van”. E konstelláció az emberek közötti idegenségérzésre utal: a közelség és távolság minden emberi relációban megfigyelhető elegyének sajátos esete ez, mely bármely eredetileg közeli kapcsolat elidegenedésekor is tetten érhető, de amely társadalmi formává, jellegzetes létállapottá mégis csupán a modernitás kontextusában válik.

Az idegen mint szociológiai fogalom nemcsak azáltal kap a térbeli dimenziókkal analóg jelentéseken túli árnyalatot, hogy fizikai értelemben valójában nem lehetséges állapotot ír le, hanem azzal is, hogy Simmel a közelség és a távolság egyaránt több dimenzióját emeli be a diskurzusba. A kollektív idegenség állapota - csakúgy, mint a sok-sok individuálisan megtapasztalt idegenség - a modern társadalmak jellegzetes hozadéka: a tipikus idegen az emancipált zsidó, aki idegenné is csak azáltal válhat, hogy szerves kapcsolatokat épít ki a többségi csoporttal. A pária népek nem idegenek, hiszen nem is részei a csoportnak, az

9 Donald Levine és szerzőtársai (1976) ennek megfelelően hangsúlyozzák, hogy minden bizonnyal ez a mondat adja a tanulmány legfőbb relevanciáját a társadalmi távolság Amerikában néhány évtizeddel később kibontakozó kutatási iránya számára. Valóban ez a gondolat hatott a leginkább megtermékenyítőleg e területre, ám éppen ez az, amely az idegen mint létállapot ellentmondásos, feszültséggel teli helyzetére, a térbeli és a társadalmi távolság sajátos elválására nem utal, szemben a szöveg egyéb részeiben vissza-visszatérő alaptézissel.

10 A szimbólum fogalma persze sokféleképpen érthető, ám úgy gondolom, éppen e terminus itteni használata az, ami miatt a mondat a későbbi szöveghelyeknél kevésbé jól ragadja meg a simmeli idegenségkoncepció árnyaltságát. 
idegen azonban, bár a többiekhez képest kevésbé tartozik a csoporthoz, mégis része annak. E szerves kapcsolat a kereskedelemmel kezdődik: az idegen eredeti alakja a távolból érkezett kereskedő, aki megtelepszik, fontos kapcsolatokat épít ki a csoporttal, de nem válik egészen csoporttaggá. Pozíciója sajátos mozgékonyságot és egyfajta objektivitást is lehetővé tesz számára: miközben mindenkivel kapcsolatban van, szervesen, erősebb szálakkal senkihez sem kötődik. A távolság és a közelség elegye ezért a közömbösség és az elkötelezettség elegye is egyben. Az objektivitás sajátos, különleges képessége jellemzi tehát az idegent, aki „még a közeli viszonyokat is madártávlatból figyeli” (i. m. 58), az objektivitás pedig egyfajta szabadság, mert „az objektív ember nem függ semmiféle meghatározottságtól, amely előre befolyásolhatná befogadását, értelmezéseinek irányultságát vagy az adottságok mérlegelését” (uo.). Az idegen a többieknél „szabadabb mind elméletben, mind gyakorlatban, hiszen elöítéletektől mentesebben képes áttekinteni a viszonyokat, amelyeket általánosabb, objektívebb ideálokhoz mér, valamint cselekvésében sem köti megszokás, kegyelet vagy bármilyen elözmény" (uo.). Mindennek következtében az idegen pozíciója, a közelség és távolság, részvétel és részvétlenség jellegzetes keveréke a társadalmi újítások potenciális forrása.

Ahogy David Frisby megállapítja (1992), Simmel térszociológiája a társadalmasodás folyamatainak szisztematikus tárgyalására irányuló - befejezetlen - projektje részeként is értelmezhető, amelyben a tér mellett az idő, a tömeg és hasonló tényezők szerepét is vizsgálta volna. „Az idegen”-ben Simmel a helyváltoztatást mint a társadalmasodás térbeli dimenziójának egy fontos aspektusát vizsgálja, vagyis arra kíváncsi, hogy a térbeli mozgás milyen új szociológiai minőségeket hoz létre. Az amerikai recepcióban azonban - ahogyan fentebb már említettem - ez az értelmezési kontextus háttérbe szorul. Jól mutatja ezt az is, hogy eredeti szövegkörnyezetében, vagyis a Soziologie térszociológiai fejezetéhez („Der Raum un die räumlichen Ordnungen der Gesellschaft”) kapcsolódva az „Exkurzus az idegenről” angolul csak 2009-ben jelent meg, az eredeti kiadás századik évfordulójának apropóján (bár azt egy évvel lekésve).

Az idegenség Simmelnél a térbeli pozíció leírásához képest számos új dimenzióval gazdagodik - azáltal válik termékeny szociológiai kifejezéssé, hogy egyszerre őriz meg valamit az eredeti - fizikai, földrajzi - értelemből, s lép azon jelentősen túl. Az idegenség értelmezését Simmel azzal tudja nemcsak plasztikussá tenni, de egyúttal szociológiai szempontból termékennyé is, hogy a fogalomban ötvözi a térbeli metaforák által kijelölt jelentéstartományt az új - társadalmi, társadalomtudományi - kontextus azt transzcendáló tartalmaival. Az amerikai szociológiában a térbeli viszonyokat, a dolgok „feltérképezését” fókuszba helyező városszociológiai kutatási irányok ellenére éppen ezek az új jelentéstartalmak váltak még hangsúlyosabbá, miközben a térbeliségből kiinduló eredeti árnyalat sokat veszített kontúrosságából.

\section{Chicago és a „marginális ember”}

Az „idegen” amerikai karrierjének - az 1921-es megjelenése után - a legfontosabb állomása Park tanulmánya volt a migrációról és a marginális emberről (Park 1928). Park érdeklődését természetesen nemcsak a Simmel, de a chicagóiak által hangsúlyosan tárgyalt kérdés, a tömeges bevándorlás nyomán kialakuló multietnikus, multikulturális városi lét jelenségei iránti érdeklődés is motiválta. Ám amint a chicagói városi zónák, körzetek sűrüjében realizálódó társadalmi jelenségek kontextusába kerül, Park marginális embere olyan vonásokra 
tesz szert, amelyek a simmeli idegennek egyáltalán nem sajátjai. Ahogyan többen (pl. Levine et al. 1976; Kurtz 1984) megjegyzik, a marginalitás Parknál emocionális és mentális problémákhoz vezet, a simmeli idegenség azonban olyan állapotot és kapcsolatot ír le, amely mindenki számára elönyös. ${ }^{11}$

A marginális ember fogalma tehát Parknál a simmeli idegenkoncepció újraértelmezéséből születik. A reinterpretáció minden bizonnyal azért érdekelte Parkot, mert az idegenség eredeti megfogalmazásában olyan problémák további kibontásának a lehetőségét pillantotta meg, amelyek az 1920-as évek amerikai - föként chicagói - szociológiáját kitüntetetten foglalkoztatták. Míg Simmelnél a kereskedő volt az idegen archetípusa, csoportként pedig az emancipált zsidóság testesítette meg azt, addig Park a modernizációval együtt járó, s Amerikában különösen látványos méreteket öltő földrajzi mobilitás, a migráció kontextusába illesztette a marginalitás fogalmát.

Közismert, hogy a chicagói kutatókat érdeklö egyik legfontosabb probléma a különböző vallási, etnikai, nyelvi hátterü csoportok együttélésének, érintkezésének a kérdése volt. Ez nem meglepő egy olyan városban, amely a megelőző néhány évtizedben az Európából és a vidéki Amerikából érkező bevándorlóknak köszönhetően a többszörösére nőtt. Park megközelítésében a marginális lét, vagyis egyfajta határállapot ennek a folyamatnak a következménye, amely egyszerre jelentkezik kulturális, társadalmi és pszichológiai dimenzióban. A marginális ember pozíciója átmeneti: a régi kötelékek felbomlanak, újak még nem alakulnak ki vagy szilárdulnak meg - ez az állapot pedig társadalmi és pszichológiai nehézségeket okoz. Egyfajta válságállapot ez, amely a marginális ember esetében viszonylag tartós, s így e kulturális átmenet az egyéni tudat szintjén is szükségképp nyomot hagy. „A marginális ember tudata az, ahol az új kulturális érintkezések által kiváltott morális zavar a legvilágosabban megnyilvánul. A marginális ember tudata - vagyis ahol a kulturális változások és fúziók lezajlanak - az, ahol a civilizáció és haladás folyamatai a legjobban tanulmányozhatók” - írja Park (1928: 893). A marginalitással együtt járó morális és mentális zavarok pedig az átmeneti állapot lezárásával, az asszimilációval szünnek meg, vagyis annak a folyamatnak a végén, amely a chicagóiak szerint a modernizációval, urbanizációval, nagy volumenü földrajzi mobilitással együtt járó kulturális érintkezés szükségszerü eredménye. Ami Simmelnél az emancipáció volt, az Parknál a migráció: a korábban kulturálisan kevéssé vagy egyáltalán nem érintkező csoportok közötti szerves kapcsolat egyfajta sajátos peremhelyzetet eredményez. Mindkettőjüknél a modernitás jelensége ez, míg azonban Simmelnél kevés negatív tartalom kapcsolódik a fogalomhoz, addig Park a marginalitásban a kulturális és morális zavar elemét hangsúlyosabban tárgyalja, s a modernizáció nyomán felbukkanó, szociológiailag releváns társadalmi problémák egyikeként konceptualizálja.

Park megközelítését árnyalta tovább egyik tanítványa, Everett V. Stonequist elöször egy tanulmányban (Stonequist 1935), majd egy teljes könyvben (Stonequist 1961 [1937]). Már Parknál is lényeges eleme volt a fogalomnak az etnikai, kulturális szempontból kevert háttér, Stonequistet pedig elsősorban azok a pszichológiai jelenségek érdekelték, amelyek a „hibrid” kulturális csoportok tagjainál figyelhetők meg. Stonequist világosan megkülönbözteti Simmel idegenfogalmát Park marginálisember-fogalmától, mivel helyesen érzékeli, hogy Simmelnél az idegenség egy alapvetően pozitívan értékelhető állapot, amely sem

11 Alább látni fogjuk, hogy Park tanítványa, Everett Stonequist ezt az eltérést korán észrevette és meg is fogalmazta, ám a különbség a további recepcióban elsikkadt, s csak e későbbi szerzők munkái nyomán került ismét előtérbe. 
az egyén, sem a csoport szempontjából nem diszfunkcionális, ${ }^{12}$ míg Park ezzel szemben a marginalitást konfliktusos, feszültségekkel teli állapotként írja le.

Stonequist számára a marginalitás legizgalmasabb eleme a speciális társadalmi állapot következtében kialakuló személyiségtípus, amelyet a korszak egyik legjelentősebb, ám sokáig kevéssé számon tartott afrikai-amerikai szociológusa, W. E. B. DuBois nyomán ír le (Stonequist 1935: 7). Eszerint e kettős identitással járó állapot olyan, mint amikor az ember egyetlen tükör helyett folyton kettőben kénytelen magát szemlélni, méghozzá két, jelentősen eltérő képet mutató tükörben. ${ }^{13}$ Mindez pedig nemcsak a társas kapcsolatokban vezet természetes módon feszültségekhez és konfliktusokhoz, hanem végül egy jól körvonalazható személyiséget alakít ki. „A 'marginális' kifejezés itt egy absztrakciós folyamatot jelez, alapvető pszichológiai vonások egy csoportjára utal, melyek a társadalmi konfliktus és azonosulás kettős mintázatának belső korrelátumai” - fogalmazza meg (Stonequist 1935: 10).

Egy másik újdonság Stonequist marginalitásértelmezésében, hogy azt nem köti kizárólag a kettős etnikai vagy kulturális identitáshoz, hanem kiterjeszti a társadalmi mobilitás olyan eseteire is, amelyeknek a korábbiaknál kevesebb közük van bármiféle földrajzi helyzetváltoztatáshoz. Felfogása szerint ilyen feszült, konfliktusos állapot és személyiségtípus bontakozhat ki például az iskolai végzettség vagy a házasság nyomán előálló gyors és nagymértékű társadalmistátusz-változások következtében is (Stonequist 1937).

A marginális ember koncepciója az amerikai szociológiában elsősorban az eltérő etnikai és kulturális csoportok érintkezésének, a bevándorlásnak és az asszimilációnak a vizsgálatára hatott megtermékenyítőleg, de néhányan megkísérelték a koncepciót egyéb marginális - bizonyos foglalkozási - csoportok vizsgálatára kiterjeszteni vagy például a társadalmi nemek tanulmányozásában kamatoztatni (Goldberg 2012). Kritikai észrevételek is korán megfogalmazódtak, ezek elsősorban a koncepció empirikus megalapozottságának a hiányát kifogásolták (pl. Green 1947; Golovensky 1952). Jogosnak tünik a kritika, hogy - amint e kritikusok rámutatnak - a koncepciót az amerikai szociológia évtizedekig komolyabb reflexió nélkül fogadta el és használta, miközben empirikus vizsgálat nem igazolta. Egy bíráló szerint nem is igazolhatta volna teljesen, hiszen a Park által leírt formában a marginalitás voltaképpen csak a vándorló, állandó lakhely nélküli, „gyökértelen” létezéshez köthető empirikusan is (Golovensky 1952).

Simmel idegenfogalma Amerikában jól láthatóan radikális átalakulásokon ment keresztül. A konceptuális megújulás, illetve átalakulás több tényezőnek köszönhető. A térbeli mozgás dimenziója absztraktabb lett, így - Pitirim Sorokin munkásságához is kapcsolódva a mobilitás fogalma itt már a társadalmi helyzet sokféle változását felöleli. A multikulturális, bevándorló csoportok sokasága által tagolt és gazdagított társadalmi lét felöl megközelítve, vagyis a többszörös kötődés, az eltérő kulturális, nyelvi, esetleg vallási, etnikai hátterű csoportokhoz való konfliktusos érzelmi és társadalmi kapcsolódás tematikája által meghatározott olvasatban pedig a marginalitás feszültségekkel terhelt társadalmi állapotként jelenik meg, jelentős kontrasztot mutatva így a Simmelnél eredetileg lényegében felszabadító idegenségállapottal.

12 Hozzá kell azonban tenni, hogy az innovációhoz is szükséges szabadság destruktív erővé válhat, ahogyan azt Simmel meg is fogalmazza: „Ez a szabadság [...] természetesen mindenféle vészterhes lehetőségeket is magában foglal” (Simmel 2004: 58). Ám semmiképp sem ez a hangsúlyos eleme.

13 Itt természetesen DuBois és Stonequist is Charles Horton Cooley 'tükör-én' fogalmából indul ki. 


\section{A fenomenológia és az idegen: Alfred Schütz}

Park - majd Stonequist - írásai nyomán az amerikai szociológia sok szerzője kapcsolódott az itt tárgyalt kérdéskörhöz. Mint láttuk, számos bírálat érte a marginális ember koncepcióját, amely ugyanakkor mégiscsak fontos és sok helyütt alkalmazott terminusként épült be a szociológiai diskurzusba. A társadalmi távolság és a mobilitás fogalmai által kijelölt, egyre inkább empirikus módszerekkel kutatott területek évtizedekre a szociológia fókuszába kerültek. Ezek bemutatása bőven túlmutatna e tanulmány keretein, a következőkben ezért már csak Alfred Schützről, arról az egy szerzőről szólok röviden, aki közvetlenül kapcsolódott Simmelhez és Parkhoz is, és az idegen koncepciójában részben ötvözte a két megközelítést, részben pedig új árnyalattal gazdagította azokat.

Mint ismert, Schütz, az osztrák tudós Husserl és a fenomenológiai irányzat követője volt. Hitler hatalomra kerülését követően sokakkal együtt emigrált; egy rövid párizsi kitérő után a New Schoolon folytatta karrierjét. Nem mellékes körülmény tehát, hogy az idegenségről szóló tanulmányba voltaképpen saját tapasztalatait is beépíthette. Eredetileg 1944-ben, már Amerikában megjelent híres tanulmányában, Az idegenben (Schütz 1984 [1944]) Park és Stonequist alapján és a bevándorlók esetére fókuszálva, pontosabban rájuk mint tipikus példára hivatkozva dolgozta ki saját koncepcióját, de Simmelre ugyancsak sok tekintetben támaszkodott. Vagyis Simmel és a chicagóiak megközelítéséből egyaránt merített, miközben mégis lényegesen új megvilágításba helyezte az idegenség szociológiai értelmezését.

Schütz világosan látja, hogy az idegen és a marginális ember fogalma nem egészen azonos: a marginalitás az idegenség állapotának állandósulását jelenti. Ám az idegenség érzése maga $s$ az általa kijelölt egyéni (vagy csoportos) pozíció sem szükségképp permanens. Schütz a kulturális mintázatok, „receptek” közötti tájékozódási zavarként értelmezi ezt az állapotot, amely azonban a sikeres tanulási folyamat végére feloldódik. Parkék marginalitásfogalmához kapcsolódva az idegen tipikus eseteként a bevándorlót írja le, aki „megkísérli értelmezni az általa megközelített társadalmi csoport kulturális mintáit, és tájékozódni próbál bennük" (Schütz 1984 [1944]: 405). Ha ezeket a kulturális mintákat nem sikerül teljesen elsajátítania, köztük eligazodnia, akkor az idegen marginális ember, egyfajta kulturális hibrid marad (i. m. 412). Ám ha sikerrel jár, akkor idegensége is megszünik.

Magától értetődőnek tekintett mindennapi tudásunk, mondja Schütz, valójában inkoherens konstrukció, mely ellentmondásai és homályossága ellenére megfelelő recepteket kínál a hétköznapokban szükséges eligazodáshoz. Csökkenti az interakciók felismeréséhez és értelmezéséhez szükséges erőfeszítés mennyiségét, cselekvési sémákat kínál fel, amelyek segítségével a hétköznapi élet gördülékenyebben zajlik. Az idegenség a sémák, receptek nem megfelelő ismeretéből adódik: az idegen észreveszi a csoport mindennapi tudásának inkonzisztenciáit, amelyek még inkább elbizonytalanítják, s mivel nem sajátította még el a cselekvési előírásokat, képtelen automatikusan eligazodni a hétköznapi helyzetekben. A csoporttagok számára természetes, megkérdőjelezetlen előfeltevéseket ő maga nem osztja, saját, hozott sémái pedig az új környezetben nem müködnek. A kulturális minták elsajátítása nélkül a magától értetődő, „típusos és anonim” attitüdöknek sincs birtokában. Mindent megkérdőjelez tehát, mindenre rácsodálkozik, így egyfajta objektivitással szemléli az új közeg mintáit. Ahhoz, hogy képes legyen kapcsolódni a csoporthoz, elöször értelmeznie kell az új közeg magától értetődőségeit, le kell fordítania, meg kell fejtenie az új nyelvet. Ahhoz pedig, 
hogy ne legyen többé idegen, belsővé kell tennie a recepteket, sémákat, az általuk előírt attitűdöket, hogy ezek végül az ő számára is magától értetődő orientációs eszközökké váljanak.

Az idegenség Schütznél a chicagóiak értelmezéséhez hasonlóan feszültséggel teli állapot, amely állandósulása esetén patologikussá válhat. Hiányzik belöle annak a szerves kapcsolatnak a képzete, amely Simmelnél az idegent a csoporthoz füzte. Simmelnél egyensúlyt látunk: az idegenség tartós helyzet, olyan állapot, melyben az idegen és a csoport valódi, kölcsönösen előnyös módon kapcsolódik egymáshoz. Idegen mivolta az egyént inkább újító szerepre predesztinálja, semmint társadalmi feszültségekkel, patológiákkal teli lét felé sodorná. A chicagóiak marginálisember-koncepciója és Schütz idegenfogalma ezzel szemben átmeneti léthelyzetet ír le csupán - új, szokatlan állapotot, mely egy normálisan zajló folyamat végére feloldódik, tartós szereppé merevedése pedig társadalmi problémaként jelenik meg.

Schütz újítása abban áll, hogy a fenomenológiai megközelítés keretében az idegenséget a hétköznapi életet szabályozó „recepttudás” hiányos ismereteként konceptualizálja. Tájékozódási zavarként, tehát voltaképpen ismerethiányként fogalmazza meg, és bár a bevándorló típusán mutatja be a fogalmat, valójában az csupán egy általános jelenség konkrét esete. Ebben az értelemben mi magunk is bármikor idegenné válhatunk helyváltoztatás vagy a társadalmi pozíció megváltozása nélkül, ha „valami korábban ismeretlenbe ütközünk, ami kirí tudásunk közönséges rendjéböl” (Schütz 1984 [1944]: 413).

Éppen ez, vagyis az idegenség általános, tipikus, sőt ideáltipikus leírása az, ami kiváltotta Schütz jó barátja, a szintén Amerikába menekülő Aron Gurwitsch rosszallását és éles kritikáját (Barber 2004). ${ }^{14}$ Gurwitsch nemtetszését fokozta a szociálpszichológiai megközelítés is, amely kétségtelenül Schütz koncepciójának sajátja. Így például érzékletesen festi le, ahogyan az idegen ügyetlenkedik, csetlik-botlik a társas szituációk útvesztőjében, nem ismerve azokat a jelentéseket, helyzetdefiníciókat, szabályokat - vagyis recepteket -, amelyek a többieket eligazítják. Voltaképpen mindez a schützi fenomenológiai szociológiába szervesen illeszkedő fejtegetés, ahol a társadalmi világ alapvetően effajta mindennapi magától értetődőségekből áll össze - az idegenség pedig sajátos esete az így interpretált társadalmi létnek. Jól látható tehát, hogy miközben nagymértékben és explicit módon támaszkodik Simmelre és a chicagóiakra is, Schütz egyúttal egy tágabb elméleti keretbe illeszti az idegen fogalmát. Gurwitsch éppen amiatt bírálja igen élesen, hogy a nácik elöl menekülök tapasztalatát, válságát egyediként értelmező leírás helyett olyan elmélettel állt elö, amely implikációit tekintve e traumatikus élményt is puszta alkalmazkodási kérdéssé redukálja (Barber 2004). Schützöt azonban e tanulmányban más érdekelte: a Simmel és a chicagóiak által felvetett fontos kérdést a mindennapi valóságot középpontba állító fenomenológiai szociológia felől közelítette meg, az idegen fogalmát pedig - ennek megfelelően - általános (mindennapi) szociológiai és szociálpszichológiai jelenségként írta le.

Az amerikai szociológia történetében Simmel az egyik legfontosabb európai szerző. Nemcsak a szociológiai kánon, a diszciplína határainak kijelölése, a tananyag kodifikálása szempontjából volt jelentősége, hanem valóban megtermékenyítőleg hatott az amerikai társa-

14 Köszönettel tartozom Havrancsik Dánielnek, hogy erre a fontos adalékra felhívta a figyelmemet. 
dalomtudományi gondolkodásra. Olyan módon tudott inspirálni, hogy gondolatainak továbbszövése, fogalmainak átültetése sajátosan amerikai kontextusokra új kutatási területeket jelölt ki. Az „idegen” szociológiai fogalmának amerikai karrierje kiválóan mutatja mindezt.

Természetesen közelről, filológiai szigorral is vizsgálható a szövegek befogadása. Föl lehet vetni a kérdést, hogy hol húzódnak egy koncepció (át)értelmezésének határai, hogy mikor beszélhetünk a jelentés gazdagodásáról vagy a koncepció beszűküléséről, mikor van szó rugalmas interpretációról, mikor pedig félreértésről. Az idegen simmeli koncepcióját a fentiekben nem ebből a szempontból tárgyaltam: arra a sokszínüségre igyekeztem rámutatni, amelyre a fogalom az amerikai értelmezés kontextusában szert tett.

Az idegenség Simmelnél nem kis mértékben különbözik attól a jelenségtől, melyet a chicagóiak a marginalitás fogalmával megragadni igyekeztek, mégsem kétséges, hogy a Park által behatóan ismert és nagyra tartott simmeli megközelítés képezte a migráció és a multikulturális, multietnikus együttélésen alapuló városi közösség vonatkozásában felvetett szociológiai problémák chicagói értelmezésének alapját. Schütz pedig, bár nyilvánvaló, hogy már korábban is ismerte a Simmel-szöveget, itt, ebben az amerikai kontextusban, a chicagóiak marginalitáskoncepciójára utalva dolgozta ki saját idegenfogalmát, amely az ő fenomenológiai szociológiájában megint újabb árnyalatot kapott.

Miközben tehát az idegen fogalma marginális emberré, majd ismét idegenné alakult különböző szerzők írásaiban, egyúttal rengeteget változott is. Ha pedig tekintetbe vesszük azokat a kutatási irányokat is, amelyekről itt nem esett szó - mint a mobilitás és a társadalmi távolság szociológiája -, akkor igazán lenyügözö, színes palettáját kapjuk azoknak a területeknek, amelyekre a fogalom minden bizonnyal megtermékenyítöleg hatott. Simmel maga talán meglepődne e sokszínűség egyes árnyalatain, ám - látva a szerteágazó recepciót - elégedetlenségre semmiképpen sem lenne oka.

\section{Hivatkozott irodalom}

Barber, Michael D. (2004): The Participating Citizen. A Biography of Alfred Schutz. Albany: State University of New York Press. DOI: https://doi.org/10.5860/choice.42-3955

Ethington, Philip J. (1997): The Intellectual Construction of „Social Distance”: Toward a Recovery of Georg Simmel's Social Geometry. Cybergeo: European Journal of Geography Epistémologie (30). DOI: https://doi.org/ $10.4000 /$ cybergeo. 227

Frisby, David (1992): Essays on Georg Simmel's Social Theory. London - New York: Routledge.

Goldberg, Chad Alan (2012): Robert Park's Marginal Man: The Career of a Concept in American Sociology. Laboratorium 4(2): 199-217.

Golovensky, David I. (1952): The Marginal Man Concept: An Analysis and Critique. Social Forces (30)3: 333-339. DOI: https://doi.org/10.2307/2571600

Green, Arnold W. (1947): A Re-Examination of the Marginal Man Concept. Social Forces (26)2: 167-171. DOI: https://doi.org/10.2307/2571773

Jaworski, Gary Dean (1995): Simmel in Early American Sociology: Translation as Social Action. International Journal of Politics, Culture, and Society 8(3): 389-417. DOI: https://doi.org/10.1007/bf02142892

Kurtz, Lester R. (1984): Evaluating Chicago Sociology. A Guide tot he Literature, with an Annotated Bibliography. Chicago - London: The University of Chicago Press. DOI: https://doi.org/10.1086/354515

Levine, Donald N., Ellwood B. Carter és Eleanor Miller Gorman (1976): Simmel's Influence on American Sociology I. American Journal of Sociology 81(4): 813-845. DOI: https://doi.org/10.1086/226143

McLemore, S. Dale (1970): Simmel's 'Stranger': a Critique of the Concept. The Pacific Sociological Review 13(2): 86-94. DOI: https://doi.org/10.2307/1388311

Némedi Dénes (2005): Klasszikus szociológia 1890-1945. Budapest: Napvilág. 
Pál Eszter (2004): „Társadalmi evolúció” és „organizmus” - avagy: mire jók a metaforák? In Az evolúció elméletei és metaforái a társadalomtudományokban. Somlai Péter (szerk.). Budapest: Napvilág, 95-116.

Pál Eszter (2004): Talcott Parsons: rendszerelmélet és organicizmus. In Kötő-jelek 2003. Némedi Dénes és Szabari Vera (szerk.). Budapest: ELTE TÁTK, 95-119.

Pál Eszter (2009): Vallás, reform és tudomány. Az amerikai szociológia kezdetei. Szociológiai Szemle 19(3): 3-25.

Pál Eszter (2015): A viktoriánus Anglia. Tudás és társadalom. Budapest: Eötvös.

Pál Eszter (2019): Tér-kép és szociológia: a „marginális ember” és az „idegen” metaforái. In Tér - tudomány - történet. Pál Eszter (szerk.). Budapest: Martin Opitz, 95-113.

Park, Robert E. (1928): Human Migration and the Marginal Man. American Journal of Sociology 33(6): 881-893. DOI: https://doi.org/10.1086/214592

Park, Robert E. (2000 [1926]): A városi közösség mint térbeli mintázat és morális rend. In Szociológiai irányzatok a XX. században. Felkai Gábor, Némedi Dénes és Somlai Péter (szerk.). Budapest: Új Mandátum, 239-247.

Park, Robert E. és Ernest W. Burgess (1921): Introduction to the Science of Sociology. Chicago: The University of Chicago Press.

Parsons, Talcott (2000 [1951]): A modern társadalmak rendszere. In. Szociológiai irányzatok a XX. században. Felkai Gábor, Némedi Dénes és Somlai Péter (szerk.). Budapest: Új Mandátum, 40-61.

Schütz, Alfred (1984 [1944]): Az idegen. In A fenomenológia a társadalomtudományban. Hernádi Miklós (szerk.). Budapest: Gondolat, 405-413.

Simmel, Georg (1973 [1903]): A nagyváros és a szellemi élet. In uő Georg Simmel. Válogatott társadalomelméleti tanulmányok. Somlai Péter (szerk). Budapest: Gondolat, 543-560.

Simmel, Georg (2004 [1908]): Exkurzus az idegenről. In Az idegen. Variációk Simmeltől Derridáig. Biczó Gábor (szerk.). Debrecen: Csokonai, 56-60.

Stonequist, Everett V. (1935): The Problem of the Marginal Man. American Journal of Sociology 41(1): 1-12. DOI: https://doi.org/10.1086/217001

Stonequist, Everett V. (1961 [1937]): The Marginal Man: A Study in Personality and Culture Conflict. New York: Russel and Russel.

\section{Pál Eszter}

Szociológus, egyetemi docens, ELTE TÁTK Társadalomelmélet Tanszék (Budapest) 